OPEN ACCESS

Edited by:

Lyne Morissette,

$M$ - Expertise Marine, Canada

Reviewed by:

Marcus Geoffrey Haward,

University of Tasmania, Australia

Manel Antelo,

University of Santiago de

Compostela, Spain

${ }^{*}$ Correspondence:

Massimiliano Cardinale

massimiliano.cardinale@s/u.se

Specialty section: This article was submitted to Marine Affairs and Policy, a section of the journal

Frontiers in Marine Science

Received: 01 February 2019

Accepted: 20 May 2019

Published: 04 June 2019

Citation:

Cardinale M, Carpi P and Scarcella G (2019) Response: Commentary: The

Saga of the Management of Fisheries

in the Adriatic Sea: History, Flaws,

Difficulties, and Successes Toward the

Application of the Common Fisheries

Policy in the Mediterranean.

Front. Mar. Sci. 6:296.

doi: 10.3389/fmars.2019.00296

\section{Response: Commentary: The Saga of the Management of Fisheries in the Adriatic Sea: History, Flaws, Difficulties, and Successes Toward the Application of the Common Fisheries Policy in the Mediterranean}

\author{
Massimiliano Cardinale ${ }^{1 *}$, Piera Carpi ${ }^{2}$ and Giuseppe Scarcella ${ }^{3}$ \\ ${ }^{1}$ Department of Aquatic Resources, Institute of Marine Research, Swedish University of Agricultural Science, Lysekil, \\ Sweden, ${ }^{2}$ Centre for Environment, Fisheries and Aquaculture Science, Lowestoft, United Kingdom, ${ }^{3}$ Italian National \\ Research Council (CNR), Rome, Italy
}

Keywords: STECF, JRC, GFCM, Adriatic sea, Nephrops norvegicus

\section{A Commentary on}

Commentary: The Saga of the Management of Fisheries in the Adriatic Sea: History, Flaws, Difficulties, and Successes toward the Application of the Common Fisheries Policy in the Mediterranean

by Dörner, H., and Casey, J. (2018). Front. Mar. Sci. 5:468. doi: 10.3389/fmars.2018.00468

Dörner and Casey (2018) published a commentary on our review paper, "The Saga of the Management of Fisheries in the Adriatic Sea: History, Flaws, Difficulties, and Successes toward the Application of the Common Fisheries Policy in the Mediterranean (Carpi et al., 2017)." However, we feel that most of their comments are largely unsupported and deserve a reply.

Dörner and Casey criticize our statement-that the role of the STECF in the regional context (in this case, the Mediterranean region) is not clearly defined-as "misleading". Yet, whereas the remit of the STECF is precisely defined on paper, it is far from being so in practice. As we argued in our review paper, this is demonstrated by the current assessment process in the Mediterranean Sea: clearly, when two different scientific advisory bodies (the GFCMSAC and the STECF) provide different advice on the same stock in the same year, but only one of them (the GFCM) is the legitimate RFMO, it is apparent that their roles are at least partially overlapping. This is especially true when considering that the GFCM is financially supported by DGMARE (around 0.8 million Euros a year; FAO., 2018) as also are the STECF and the JRC (around 2.1 million Euros overall; https:/ec.europa.eu/fisheries/cfp/emff/annual-workprogramme-grants-and-procurement_en). Thus, tax money was spent to finance two assessments of the same stock by two different organizations in the same year. Their different results have created a management impasse and have confused stakeholders as to which advice should be acted on. If this is not an instance of unclear definition of the roles of the two bodies (which we feel it plainly is), it is at the very least a huge waste of public money. 
Dörner and Casey also criticize our statement that the Norway lobster assessment model in the Adriatic Sea was imposed by the JRC, invoking the absence of a minority statement in the report. Yet, the disagreement was in fact stated in the report, and in considerable detail (see section 5.2.6.9 in STECF, 2016). Moreover, since we participated in that working group, we can truthfully state that most of the experts from the Adriatic institutions believed that a combined model (GSA 17 and 18) for Norway lobster was not scientifically robust, whereas the JRC representatives essentially forced a vote for its adoption, in effect ignoring the strong expertise on Adriatic Norway lobster embodied at the meeting.

Dörner and Casey also consider some of our critiques to the STECF-specifically "its reluctance in involving non-EU scientists in the scientific discussion in the Mediterranean context" and "a recent tendency of imposing its view and modus operandi in scientific fora"-as "unsubstantiated." Yet, Table 1 of our review paper clearly illustrates the lack of participation of non-EU scientists in the STECF Working Groups, thus demonstrating that the first point is a matter of fact, not opinion. Besides, while participants in the STECF Expert Working Groups are indeed invited by the European Commission according to their professional expertise, it can hardly be denied that scientists from non-EU States could provide valuable contributions to the discussion on and management of stocks shared with non-EU countries. It is also worth stressing that we never suggested that scientists are invited to the STECF Working Groups based on national affiliation.

Our criticism of the modus operandi of the STECF and of the fact that the JRC appears to be on its way to becoming a decision-making organ has been inspired both by the assessment of Norway lobster in the Adriatic Sea, reported above, and by our experience as STECF Working Group members for more than a decade. We stressed that "This experience is leaving scientists with the impression of not being free to think and act according to their expertise (as they are, in theory, called to

\section{REFERENCES}

Carpi, P., Scarcella, G., and Cardinale, M. (2017). The saga of the management of fisheries in the Adriatic Sea: history, flaws, difficulties and successes towards the application of the common fishery policy in the Mediterranean. Front. Mar. Sci. 4:423. doi: $10.3389 /$ fmars.2017.00423

Dörner, H. and Casey, J. (2018). Commentary: the saga of the management of fisheries in the adriatic sea: history, flaws, difficulties, and successes toward the application of the common fisheries policy in the Mediterranean. Front. Mar. Sci. 5:468. doi: $10.3389 /$ fmars. 2018.00468

FAO. (2018). Report of the Forty-First Session of the General Fisheries Commission for the Mediterranean (GFCM), Budva, Montenegro, 16-20 October 2016. GFCM Report No. 41, Rome.

STECF (2016). Reports of the Scientific, Technical and Economic Committee for Fisheries (STECF) - Mediterranean Assessments Part 2 (STECF-16-08). do in these occasions)." As Dörner and Casey note, there is no tangible proof for this impression. However, as the eponymous detective Hercule Poirot allegedly said, "One coincidence is just a coincidence, two coincidences are a clue, three coincidences are a proof," which is well-suited here.

As stressed by Dörner and Casey, during the STECF plenary meeting all members have the opportunity to contribute to the decisions regarding an assessment. Yet, this is largely theory, since the current system does not effectively ensure that this opportunity can be exercised. In fact, plenary sessions are demanding in terms of workload, each scientist has a different task and, as often happens in these situations, each discussion is restricted to a few members of the plenum. This is true of the STECF plenary, in which two of the authors have participated for more than a decade, as of most types of working groups. Yet, in the case of the STECF this entails that the experts who carried out an assessment may also be those charged with scrutinizing it. This is why we highlighted the need for external, independent peer review. Unlike the assessments of other international bodies, e.g., the ICES, IOTC, and lately the GFCM itself, most STECF assessments are not formally reviewed. Surely, "a consensus view of the entire committee" is a poor substitute for peer review.

Finally, our long-standing involvement and role in the STECF plenary sessions as well as in several STECF, GFCM, and ICES Working Groups are in the public domain and just one google click away. Moreover, we feel that in providing a first-hand, comprehensive knowledge of the issues we have examined, they actually enhance the value and ensure the unbiased nature of the discussion, making our contribution an objective review, not an opinion paper.

\section{AUTHOR CONTRIBUTIONS}

All authors listed have made a substantial, direct and intellectual contribution to the work, and approved it for publication.

Publications Office of the European Union, Luxembourg, EUR 27758 EN, JRC 101548, 483.

Conflict of Interest Statement: The authors declare that the research was conducted in the absence of any commercial or financial relationships that could be construed as a potential conflict of interest.

Copyright (๑ 2019 Cardinale, Carpi and Scarcella. This is an open-access article distributed under the terms of the Creative Commons Attribution License (CC BY). The use, distribution or reproduction in other forums is permitted, provided the original author(s) and the copyright owner(s) are credited and that the original publication in this journal is cited, in accordance with accepted academic practice. No use, distribution or reproduction is permitted which does not comply with these terms. 